Journal of Primary Education
$9(5)(2020): 536-545$
UNNES
https://journal.unnes.ac.id/sju/index.php/jpe

\title{
Development of Maritime Insight Learning Tools for Ocean Literacy in Children Aged 5-6 Years Old
}

\author{
Nanang Sahriana ${ }^{1 凶}$, Tri Suminar ${ }^{2}$,Yuli Kurniawati Sugiyo Pranoto ${ }^{2}$ \\ DOI: https://doi.org/ 10.15294/jpe.v9i5.43530 \\ ${ }^{1}$ Pendidikan Guru-Pendidikan Anak Usia Dini, Universitas Halu Oleo, Indonesia \\ ${ }^{2}$ Pascasarjana, Universitas Negeri Semarang, Indonesia
}

\begin{abstract}
Article Info
Abstract

History Articles

Indonesia as an archipelagic country should be introduced to early childhood.

Received:

20 September 2020

Accepted:

21 October 2020

Published:

31 December 2020

Therefore, it is necessary to develop maritime insight learning tools for children in coastal areas. The objectives of this research were to develop maritime insight learning tools for ocean literacy in children aged 5-6 years old and to analyze the effectiveness of the learning tools. The learning tools were in the form of semester program, weekly and daily lesson plan, teaching materials, and learning media and were developed by following the conditions and

Keywords: learning tools, maritime, ocean literacy, early childhood. characteristics of the coastal areas. Research \& Development with one group pretest-posttest design were conducted in six kindergartens with 80 students at Konawe Utara Regency, Southeast Sulawesi. The research also involved education experts, practitioners, and teachers of that areas as research subjects. Data collection instruments used were observation sheets, questionnaires, tests, and documentation. The results showed that the maritime insight learning tools is valid for use. The result of trials with t-test showed there were an increase in the ocean literacy skills of students after using maritime insight learning tools with $\mathrm{n}$-Gain scores of 0.69 with the category medium on a limited scale trial and 0.70 with the high category in wide scale trial. It concluded that development of the maritime insight learning tools was effective for improving ocean literacy in children aged 5-6 years old.
\end{abstract}

\footnotetext{
$\bowtie$ Correspondence address:

Papandayan 1, Bendan Ngisor, Gajah Mungkur, Kota Semarang.

E-mail: nanang.sahriana@gmail.com
} 


\section{INTRODUCTION}

Indonesian's geographic location leads Indonesia a maritime country, but the concept of maritime affairs has not been well and implanted in learning activities, especially early childhood education which is the most basic level of education. All this time, marine knowledge in schools has not become the focus and only gets a small portion of the national education curriculum. Consequently, Indonesian students do not have positive knowledge, attitudes, and perceptions of maritime affairs.

Gandha and Pranata (2015) noted that the underdevelopment of Indonesian children's knowledge of Indonesian nature, especially in the maritime sector, is caused by the educational curriculum is still center on teachers and textbooks without direct interaction with the learning object. It is should become a serious concern, because when these children grow up and become teachers, they do not have the connection with the sea to teach effectively about marine in the classroom (Dromgool et al., 2017). Also, teachers' understanding is still low about the curriculum in coastal areas (Puspitasari and Febrialismanto, 2016).

Lack of knowledge and public interest in the marine can cause damage extinction threat for marine life in Indonesia. According to Fletcher et al. (2009), they stated that the low level of public knowledge and awareness is due to limited information about marine affairs. The maritime sector is not very popular in the field of education in various countries like Indonesia, so it does not get much attention. This is evidenced by the lack of literature on marine education and many researchers who have not focused on this area (Umuhire and Fang, 2016). Besides, marine education is the rarest focus of study and is very difficult to find because research methodologies related to marine are quite difficult to do in kindergartens (Hapidin, Nurjannah, and Hartati, 2018).

One of the efforts to increase knowledge and interest in marine is education from an early age (Crec, Noventius and Bayu, 2018). Steel et al. (2005) argued that increasing public awareness and knowledge of the oceans would increase support for marine restoration efforts. Therefore, a curriculum with maritime content needs to be given to children from an early age so that they know their national identity and that children have an attitude of pride and love for the country.

Marine education is very important in helping children develop the knowledge, skills, and attitudes needed to preserve the environment, especially coastal ecosystems in the future (Syarah et al., 2019). The introduction of the surrounding natural environment is necessary so that children know their environment and instill a sense of love for their environment and understand the importance of the sea for the future (Khamidun, 2012; Matsumoto et al., 2017; Sakurai, Uehara, and Yoshioka, 2019). Furthermore, Chabanet et al. (2018) emphasized that environmental education for children is one of the basic tools needed to reverse the state of environmental degradation and erosion of biodiversity.

Indonesia's aspiration to return to a maritime axis has also stated in the National Long Term Development Plan (RPJPN) 20052025 in point 7 of the national development mission, namely to make Indonesia an independent, advanced, strong archipelago and based on the interests of national sovereignty. It is also a serious concern of President Joko Widodo, who emphasizes the direction of building his cabinet by re-initiating the triumph of the Indonesian nation as a maritime country (Prabowo, 2014).

The maritime loaded curriculum is an effort to provide knowledge and introduce children to nautical or marine life. The maritime loaded curriculum aims to direct early childhood to better understand local potential by exploring Indonesian's marine wealth and elevating the nation's image as a maritime nation. The role of education in instilling a maritime spirit is to include maritime content in the early childhood education (ECE) 2013 curriculum.

All this time, the marine concept has been limited and marginalized in the curriculum, due to limited public knowledge of the principles of 
the seabed and not ready to make the right decisions (McPherson et al., 2018). The marine theme is still a theme that has not been taught much in ECE (Zellawati, 2017). Early childhood as the next generation of the ideals of the nation's struggle is the most important part of the national development process as a human investment and as a maritime country, an understanding or feeling of loving the marine world for children must develop from an early age. Irawan (2018) revealed that for maritime education to be successful, students must have good ocean literacy. Ocean literacy does not have to separate material in the ECE curriculum, but maritime material is embedment in every learning theme and activity in kindergarten.

Santoro et al. (2017) defines ocean literacy is an understanding of the influence of the oceans on us, and our influences on the oceans to live and act responsibly for the future. There were seven basic principles of ocean literacy, including 1) the ocean is an inseparable unit and has many characteristics, 2) the oceans and life in them form the characteristics of the earth, 3) the oceans are the main determinants of weather and climate, 4) ) the existence of the oceans is the reason why the earth is habitable to live in, 5 ) the oceans have a large wealth of biodiversity and ecosystems, 6) the oceans and humans have a very close relationship, and 7) most of the oceans have not been explored.

Ocean literacy is a way not only to raise public awareness about the oceans but also as an approach to encourage all communities and stakeholders to have more responsible and informed behavior towards the oceans and its resources (Guest et al., 2015; Fauville, 2017; Santoro et al., 2017; Tsai and Chang, 2019).

A person is said to have good ocean literacy if he has the following 3 important aspects, firstly knowledge of the ocean, secondly having a good attitude towards the marine environment and not violating marine values, and thirdly having good behavior towards the marine environment (Strang et al., 2007; Hindrasti and Irawan, 2018). These three aspects are used as indicators for assessing ocean literacy in early childhood (5-6 years old).

A teacher needs to prepare a lesson plan before teaching. Learning planning or learning tools is a teacher's main tool that must be prepared in the face of the learning process in the classroom and becomes a benchmark for professional teachers in evaluating each teaching result.

ECE have given the freedom to create their learning programs are referred to as Permendikbud number 146 of 2014 concerning the Early Childhood Education 2013 curriculum. However, in reality in the field, there are still many ECE educators who have difficulty in developing lesson plans that are following conditions in coastal areas.

The objectives of this research were to develop maritime insight learning tools for ocean literacy in children aged 5-6 years old and to analyze the effectiveness of the learning tools for improving ocean literacy in children aged 5-6 years old. These learning tools were in the form of semester program, weekly lesson plan, daily lesson plan, teaching materials, and learning media. This research was expected to be a reference for research on ocean literacy in children.

\section{METHOD}

This research was a research and development model of the Borg \& Gall that adapted to the needs of research, which was divided into 3 stages, namely preliminary stage, development stage, and trials stage. This research was conducted in six kindergartens, namely TK Konasara, TK Nurul Hidayah, TK Wisata Tanjung Taipa, TK Tongalino, TK Mawar, and Kindergarten Mekar Sari at Konawe Utara Regency, Southeast Sulawesi with the research subjects of children group B (56 years old) of 80 children. Sources of research data come from education experts and practitioners, teachers, and students. The research design of this study was preexperimental design with the type one group pretest-posttest design. 
The data collection instruments used were observation sheets, questionnaires, tests, and documentation. Learning tools validity was obtained from expert validity. Learning tools effectiveness was obtained from the t-test and $\mathrm{n}$ Gain test, both of them accuired from development stage.

Referring to the ocean literacy assessment instrument developed by Hindrasti and Irawan (2018) has been declared valid and reliable, this research instrument refers to this instrument and has been modified according to the research needs of early childhood.

Indicators of tests ocean literacy consist of 3 important aspects, namely marine insight, caring attitude towards the marine environment, and behavior towards the marine environment. These three aspects were then developed according to the research needs so that they become 10 item questions to measure ocean literacy in children (5-6 years old).

\section{RESULTS AND DISCUSSION}

\section{Learning Tools Validation}

Expert validators and practitioners assess that maritime insight learning tools in the form of semester program, weekly lesson plan, daily lesson plan, teaching materials, and learning media developed can be used with minor revisions. There were several revised components, such as materials that must adjust to the child's age, display layout, use simple sentences, semester programs adapted to the ECE 2013 curriculum format, use of the surrounding environment for children's learning and have been revised according to the validator's suggestion. The results of the assessment of all maritime insight learning tools developed presented in Table 1.

Table 1. The Result of Learning Tools Validation

\begin{tabular}{llllll}
\hline \multirow{3}{*}{ Code } & \multicolumn{2}{l}{ Learning Tools } & & \\
\cline { 2 - 6 } & Semester & Weekly Lesson & Daily Lesson & Teaching & Learning \\
& Program & Plan & Plan & Material & Media \\
\hline V-1 & 47 & 34 & 77 & 31 & 27 \\
V-2 & 42 & 29 & 74 & 30 & 26 \\
V-3 & 46 & 32 & 75 & 31 & 27 \\
Average & 4.5 & 4.5 & 4.4 & 4.4 & 4.4 \\
Category & Valid & Valid & Valid & Valid & Valid \\
\hline
\end{tabular}

Based on Table 1, it concluded that the validity test on maritime insight learning tools in early childhood education obtained an average value of 4.44 with a percentage of $88.8 \%$ indicated the category was valid to be tested further in research.

The validator considers that this maritime insight learning tool was valid to be given to kindergartens in coastal areas so that children grow with high maritime enthusiasm and values because currently, children's interest in marine is still low (Sulistiani and Mustami'ah, 2015; Fuad and Musa, 2017; Wardani, Sa'ida, and Abidin, 2019). Learning with the marine theme is the right and effective step in overcoming the low interest in marine in early childhood and providing learning experiences for children about marine.

Valid learning tools were still being repaired first, based on the validator's advice before being used for further trials. Suggestions and follow-up from the learning tools validity test can be seen in Table 2 of the learning tools improvements.

Learning activities in ECE currently do not highlight the potential of coastal areas, therefore in this research include the theme of marine plants with the sub-theme of mangroves, coral reefs, and seaweed in learning activities. The results of interviews with teachers indicated 
that the theme of marine plants was considered quite interesting and very suitable to be applied in kindergartens located in coastal areas because this theme had not existed before and the children's environment was supportive. Another consideration was that there are many mangrove forests and coral reefs that have been damaged by human activities, which are increasing every year (Susiloningtyas, Handayani, and Amalia, 2018). Seeing this condition, it can be concluded that this theme is very important to be applied to early childhood education. Several tools were needed had been revised as presented in Table 2 .

Table 2. The Learning Tools Improvement

\begin{tabular}{|c|c|c|}
\hline $\begin{array}{l}\text { Learning Tools } \\
\text { Aspects }\end{array}$ & Validators Suggestion & Revisions \\
\hline Content & $\begin{array}{l}\text { The material was adapted to the level } \\
\text { of early childhood development } \\
\text { Teaching materials were made more } \\
\text { specific }\end{array}$ & $\begin{array}{l}\text { Material adapted to children aged 5-6 } \\
\text { years } \\
\text { Teaching materials were made into } 3 \\
\text { series, namely mangroves, coral } \\
\text { reefs, and seaweed }\end{array}$ \\
\hline $\begin{array}{l}\text { Basic } \\
\text { Competencies }\end{array}$ & Adjust to the 2013 ECE Curriculum & ECE Curriculum \\
\hline Language & $\begin{array}{l}\text { The sentences used were simpler so } \\
\text { that children can easily implement } \\
\text { them }\end{array}$ & The sentences used were simpler \\
\hline Graphical & $\begin{array}{l}\text { Lay out appearance was made to be } \\
\text { more attractive } \\
\text { The picture is clarified }\end{array}$ & Lay out was made attractive \\
\hline
\end{tabular}

Suggestions regarding the improvement of learning tools were made to improve the word used to be more simpler, so that make it easier for teacher and students to understand on learning tools. Use material adapted to the level of early childhood education aged 5-6 years. The source of the picture is included both from the internet and printed books. Competencies adjusted to the ECE curriculum. Teaching materials were made into 3 series, namely mangroves, coral reefs, and seaweed. Besides, improvements were also made to the color arrangement, to make it more interesting, and use striking colors. Improvements can be seen in Figures 1 (a) and (b).
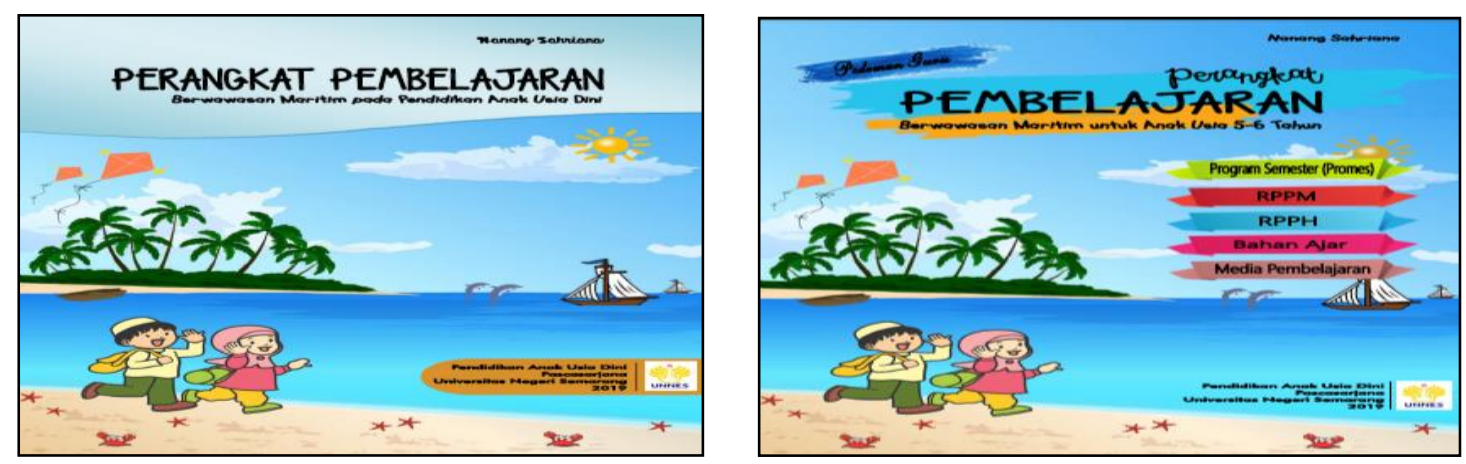

Figure 1a. Cover Before-After Revision 

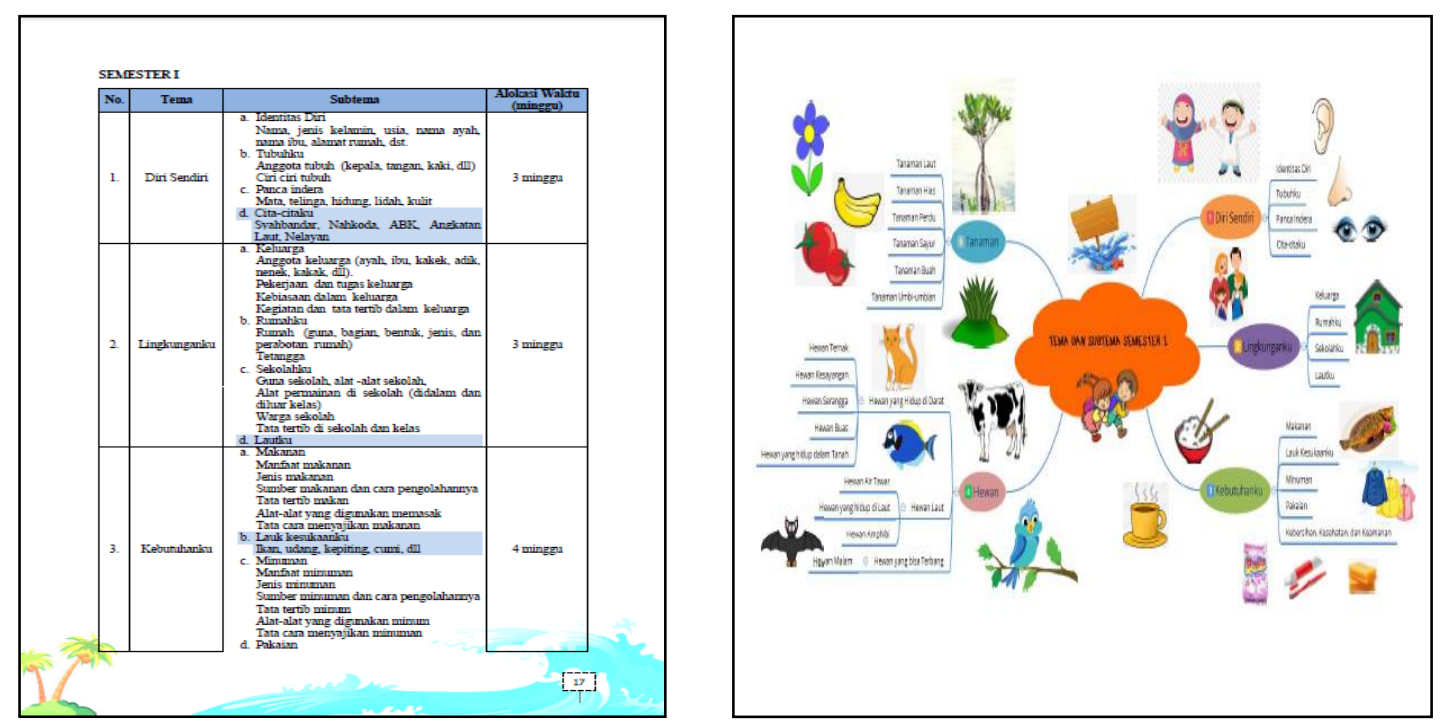

Figure 1b. Teaching Material Before-After Revision

After learning tools is declared valid, the next stage is the trials stage of the application of learning tools into the learning process. This stage is carried out by limited scale and wide scale trials to the classes and is seen to be effective.

\section{Effectiveness of Learning Tools}

Before testing the effectiveness of maritime insight learning tools, there were several staged to be carried out.

Hypothesis Test

Hypothesis testing was carried out using the t-test assisted by SPSS version 24 and the sig results were obtained, 0.000 (2-tailed) for learning outcomes at pre-test and post-test scores. So it concluded that $\mathrm{H}_{0}$ was rejected.

\section{Effectiveness Test}

\section{Limited Scale Trial}

In a limited scale trial on learning tools, 15 students were carried out at Konasara Kindergarten as a sample. Teachers are given maritime insight learning tools that have been developed. The results of the calculation of the pre-test and post-test values can be seen in Table 3.
Table 3. Limited Scale Pre-test and Post-test Results

\begin{tabular}{lllll}
\hline & Mean & N & $\begin{array}{l}\text { Std. } \\
\text { Deviation }\end{array}$ & $\begin{array}{l}\text { Std. } \\
\text { Error } \\
\text { Mean }\end{array}$ \\
\hline Pretest & 4.9333 & 15 & .96115 & .24817 \\
Posttest & 8.4667 & 15 & .63994 & .16523 \\
\hline
\end{tabular}

Based on Table 3 the sample was used in a limited scale trial using maritime insight learning tools with three learning sub-themes, namely mangroves, coral reefs, and seaweed, namely 15 children. The mean score for the pretest was 4.93, while in the post-test it was 8.46. This shows an increase in the average value between the initial (pre-test) and the final (posttest) scores. The findings during this limited scale trial were used as consideration to make improvements to maritime insight learning tools in early childhood (5-6 years old).

The results of observations and children's learning activities during maritime learning activities, it can improve ocean literacy in early childhood including aspects of children's marine insight, children's caring attitudes towards the marine environment, and children's behavior towards the marine environment. The increase is presented in Figure 2. 


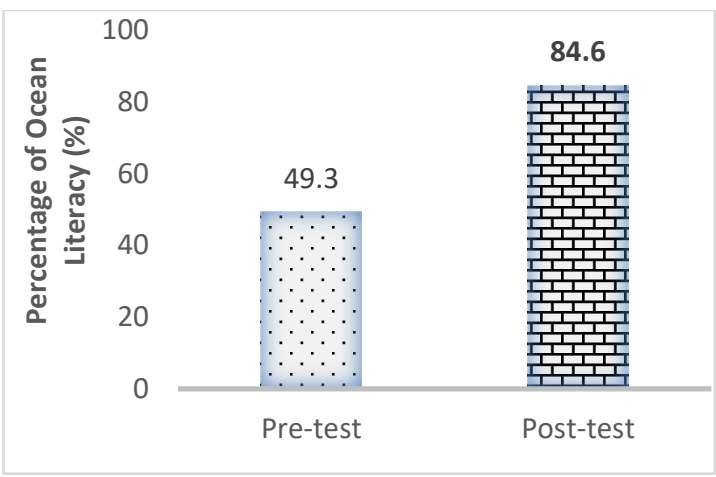

Figure 2. The Percentage of Ocean Literacy in Limited Scale Trial

The limited scale trial stage of maritime insight learning tools, several obstacles were encountered, including a) the learning theme that was applied for the first time made children confused, b) there were several terms that children did not understand, because children often used regional languages in communicating with teachers, c) unclear instructions in children's activities, and d) insufficient image size. The findings during this limited scale trial was taken into consideration to be improved.

Wide Scale Trial

The results of wide scale trial on maritime insight learning tools were carried out by 65 students in five kindergartens, namely Nurul Hidayah Kindergarten, Wisata Tanjung Taipa Kindergarten, Tongalino Kindergarten, Mawar Kindergarten, and Mekar Sari Kindergarten. To find out the average value obtained in the pretest and post-test, it can be seen in Table 4 .

Table 4. Wide Scale Pre-test and Post-test Results

\begin{tabular}{lllll}
\hline & Mean & $\mathrm{N}$ & $\begin{array}{l}\text { Std. } \\
\text { Deviation }\end{array}$ & $\begin{array}{l}\text { Std. } \\
\text { Error } \\
\text { Mean }\end{array}$ \\
\hline Pretest & 4.9385 & 65 & 1.17096 & .14524 \\
Posttest & 8.5385 & 65 & .61433 & .07620 \\
\hline
\end{tabular}

Based on Table 4 it can be seen that the average value achieved in the pre-test is 4.94 and the average value achieved in the post-test is 8.54. This shows an increase in the average value between the initial (pre-test) and the final (post-test) scores.
Based on the results of observations and children's learning activities during maritime learning activities, it is considered to be able to improve ocean literacy in early childhood. The increase can be seen in Figure 3.

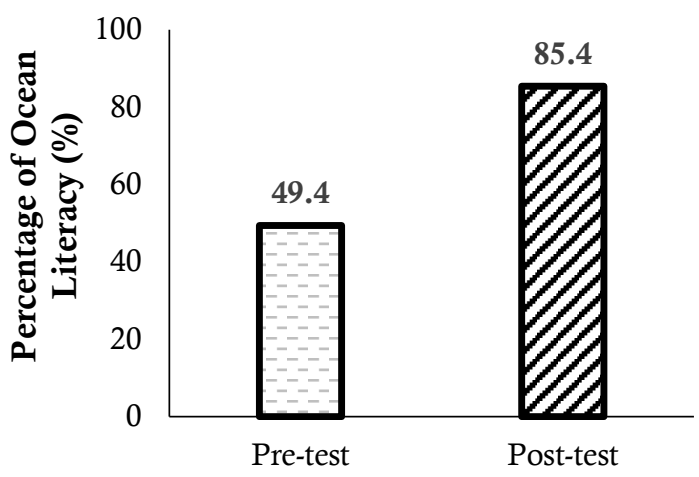

Figure 3. The Percentage of Ocean Literacy in Wide Scale Trial

The development of maritime insight learning tools is carried out using the Borg and Gall model which is then adjusted to the research needs. This research is relevant to research conducted by Sulistiani and Mustami'ah (2015) with research subjects in kindergartens located in the coastal area of Kedung Cowek Kenjeran Surabaya, stating clearly that the need for an introduction to marine themes in children around the coastal areas through learning in kindergarten. Alqadri et al. (2018) noted that children as the nation's next generation were needed to have knowledge and skills in maintaining and preserving Indonesia's natural wealth appropriately and wisely.

Fuad and Musa (2017) stated that thematic education a given marine can improve children's interest in the maritime field. Marine thematic education in kindergarten can be started in a way introduction to the maritime profession, tools transportation, biota images and the environment the sea. Hapidin et al. (2018) support this study, researched the integrative thematic learning in implemented maritime education in early childhood education, and concluded that integrative thematic conceptual learning model to be an 
alternative and contribute to implement marine education from an early childhood.

The effectiveness test was carried out by comparing the initial score and the final score through the t-test. Analysis of t-test data in this study using the paired sample test. The results of the t-test can be seen in Table 5 .

Based on the data, it can be seen that the Asymp Sig. (2-tailed) was 0.000 . It means that
$0.000<0.05$ with $\mathrm{H}_{0}$ rejected and $\mathrm{H}_{\mathrm{a}}$ accepted because there is a difference in the average score obtained.

As for knowing the truth of the hypothesis with $t_{\text {count }}>t_{\text {table, }}$ which means if $t_{\text {count }}>t_{\text {table }}$ then $\mathrm{H}_{0}$ is rejected, whereas if $\mathrm{t}_{\text {count }}<\mathrm{t}$ table then $\mathrm{H}_{0}$ is accepted. Based on the data in table 4, it can be concluded that $\mathrm{t}$ count $>\mathrm{t}$ table, namely $24.808>1.998$.

Table 5. Paired Sample Test

\begin{tabular}{|c|c|c|c|c|c|c|c|c|}
\hline & \multirow[t]{2}{*}{ Mean } & \multirow[t]{2}{*}{$\begin{array}{l}\text { Std. } \\
\text { Deviation }\end{array}$} & \multirow[t]{2}{*}{$\begin{array}{l}\text { Std. Error } \\
\text { Mean }\end{array}$} & $\begin{array}{l}95 \% \\
\text { Interval } \\
\text { Difference }\end{array}$ & $\begin{array}{l}\text { Confidence } \\
\text { of the }\end{array}$ & $\mathrm{t}$ & $\mathrm{df}$ & \multirow[t]{2}{*}{$\begin{array}{l}\text { Sig. } \\
\text { tailed) }\end{array}$} \\
\hline & & & & Lower & Upper & & & \\
\hline $\begin{array}{l}\text { Pre- } \\
\text { test } \\
\text { Post- } \\
\text { test }\end{array}$ & 3.60000 & 1.16994 & .14511 & $\begin{array}{l}- \\
3.88990\end{array}$ & -3.31010 & -24.808 & 64 & .000 \\
\hline
\end{tabular}

The results of the analysis of the test data on the effectiveness of maritime insight learning tools through Asymp Sig. (2-tailed) and t-test it can be concluded that $\mathrm{HO}$ is rejected and $\mathrm{Ha}$ is accepted where there is a significant difference between children's learning outcomes in the pretest and post-test. It can be said that this maritime insight learning tool is effective for improving ocean literacy in children aged 5-6 years old and can be used in learning activities in ECE.

The maritime insight learning tools in early childhood (5-6 years old) are an effort to develop a planned learning program to present fun, creative, and interactive learning to help students acquire knowledge of attitudes, knowledge, values, and behaviors that refer to culture maritime. One of the learning themes developed is the theme of marine plants with the sub-theme of mangroves, coral reefs, and seaweed. This is in line with the opinion of Kurniati (2017) noted that the coast is a natural learning media for early childhood. Learning activities are supported by teaching materials and learning media. This study found that the use maritime insight learning tools with a valid can be well integrated through various learning activities for children in coastal area. Children can improve their understanding of the impact of marine environment on human life.

\section{CONCLUSION}

Based on the results of research conducted on development of maritime insight learning tools, is proven to increase students' ocean literacy in children aged 5-6 years old. So it can be concluded that the development of development of maritime insight learning tools proved to be valid and effective use in the learning of kindergarten group B (5-6 years old).

\section{REFERENCES}

Alqadri, Z., \& Solihat, R. (2018). Development of Scientific Literacy-Based Instructional Material on The Beach Theme. In Proceeding of International Conference: Primary Education Pivotal Literature and Research UNNES 2018 (p. 89-99).

Chabanet, P., Stoica, G., Carrière, S. M., Sabinot, C., Bedrossian, C., \& Ferraris, J. (2018). Impact of the Use of a Teaching Toolbox in an Awareness Campaign on 
Children's Representations of Coral Reefs. Frontiers in Marine Science, 5: 340.

Crec, A. S., \& Noventius, C. (2018). Media Interaktif Virtual Reality Biota Laut Indonesia Sebagai Media Pembelajaran Untuk Usia 11-13 Tahun. In Seminar Nasional Seni dan Desain 2018 (pp. 251258). State University of Surabaya.

Dromgool-Regan, C., Burke, N., \& McClouglin, T. J. J. (2017). Marine Deficit Disorder: Marine Literacy in Primary Student Teachers. In Proceedings of the ESERA 2017 Conference, Dublini.

Fauville, G. (2017). Questions as Indicators of Ocean Literacy: Students' Online Asynchronous Discussion with a Marine Scientist. International Journal of Science Education, 39(2), 1-20.

Fletcher, S., Potts, J. S., Heeps, C., \& Pike, K. (2009). Public Awareness of Marine Environmental Issues in the UK. Marine Policy Journal, 33(2), 370-375.

Fuad, M. A. Z., \& Musa, M. (2017). Pengenalan Bidang Kemaritiman Sejak Usia Dini melalui Pembelajaran Tematik Kelautan pada Siswa Taman Kanak Kanak. Jurnal Pendidikan Geografi, 22(2), 93-104.

Gandha, M. V., \& Pranata, H. R. (2015). Penerapan Aspek Perkembangan Anak dalam Perancangan Sekolah Alam Baruna Bahari. Jurnal Kajian Teknologi, 11(1), 94-103.

Guest, H., Lotze, H. K., \& Wallace, D. (2015). Youth and The Sea: Ocean Literacy in Nova Scotia, Canada. Marine Policy Journal. 58, 98-107.

Hapidin., Nurjannah., \& Hartati, S. (2018). Pengembangan Model Pembelajaran Tematik Integratif Berbasis Proyek dalam Menerapkan Pendidikan Kelautan pada Anak di Kepulauan Seribu. Jurnal Pendidikan Usia Dini. 12(1), 51-65..

Hindrasti, N. E. K., \& Irawan, B. (2018). Pengembangan Instrumen Penilaian Literasi Kelautan untuk Siswa SMA. Jurnal Kiprah 6(2), 1-7.

Irawan, B. (2018). Framework Literasi Kelautan Sebagai Acuan Pembelajaran Sains di
Negara Maritim. Pedagogi Hayati, 2(1), 1423.

Kementerian Pendidikan dan Kebudayaan. (2013). Peraturan Menteri Pendidikan dan Kebudayaan Republik Indonesia Nomor 146 Tahun 2014 tentang Kurikulum 2013 Pendidikan Anak Usia Dini.

Khamidun, M. (2012). Environmentally Awareness Behaviour Increase in Early Childhood Using Story Telling Method. Indonesian Journal of Early Childhood Education Studies, 1(1), 32-36.

Kurniati, A. (2017). Pesisir Pantai Lakorapu Sebagai Media Pembelajaran Alami bagi Anak Usia Dini. JEC (Jurnal Edukasi Cendekia), 1(1), 1-15.

Matsumoto, K., Takeno, K., Urata, M., Matsubara, M., Kato, T., Suzuki, N., \& Hayakawa, K. (2017). Evaluation of Marine Education's Effect in Elementary and Junior High Schools-Analysis of the Value Consciousness Using Text Mining. American Journal of Educational Research, 5(1), 76-81.

McPherson, K., Wright, T., \& Tyedmers, P. (2018). Examining the Nova Scotia Science Curriculum for International Ocean Literacy Principle Inclusion. International Journal of Learning, Teaching and Educational Research, 17(11), 1-16.

Prabowo, D. (2014). Jokowi, Poros Maritim Dunia, Tol Laut, dan "Si Vis Pacem Para Bellum". Kompas News.

Rencana Pembangunan Jangka Panjang Nasional (RPJPN) 2005-2025.

Santoro, F., Selvaggia, S., Scowcroft, G., Fauville, G., \& Tuddenham, P. (2017). Ocean Literacy for All: A Toolkit (Vol. 80). UNESCO Publishing.

Steel, B. S., Smith, C., Opsommer, L., Curiel, S., \& Warner-Steel, R. (2005). Public Ocean Literacy in The United States. Ocean \& Coastal Management, 48(2), 97114.

Sakurai, R., Uehara, T., \& Yoshioka, T. (2019). Students' Perceptions of a Marine Education Program at a Junior High School in Japan with a Specific Focus on 
Satoumi. Environmental Education Research, 25(2), 222-237.

Sulistiani, W., \& Mustami'ah, D. (2015). Pembelajaran Tematik Kelautan Kemaritiman dan Minat Kebaharian pada Anak Usia Dini di Taman KanakKanak Daerah Pesisir. Poseidon: Jurnal Ilmiah Psikologi dan Psikologi KelautanKemaritiman, 9(1), 1-16.

Susiloningtyas, D., Handayani, T., \& Amalia, A. N. (2018). The Impact of Coral Reefs Destruction and Climate Change in Nusa Dua and Nusa Penida, Bali, Indonesia. Earth and Environmental Science, 145(1), 1254.

Syarah, E., Yetti, E., Fridani, L., Yufiarti, Y., Hapidin, H., \& Pupala, B. (2019). Electronic Comics in Elementary School Science Learning for Marine Conservation. Jurnal Pendidikan IPA Indonesia, 8(4), 500-511.
Tsai, L. T., \& Chang, C. C. (2019). Measuring Ocean Literacy of High School Students: Psychometric Properties of a Chinese Version of the Ocean Literacy Scale. Environmental Education Research, 25(2), 264-279.

Umuhire, M. L., \& Fang, Q. (2016). Method and Application of Ocean Environmental Awareness Measurement: Lessons Learnt from University Students of China. Marine Pollution Bulletin, 102(2), 289-294.

Wardani, C., Sa'ida, N., \& Abidin, R. (2019). Pengaruh Pembelajaran Tematik Kelautan Terhadap Penanaman Karakter Kebaharian pada Anak Usia 5-6 Tahun di TK Hang Tuah 12 Surabaya. Pedagogi: Jurnal Anak Usia Dini dan Pendidikan Anak Usia Dini, 5(2), 67-72.

Zellawati, A. (2017). Mengasah Kecerdasan Naturalistik melalui Pendidikan Cinta Kelautan pada Anak Usia Dini. Jurnal Sains dan Teknologi Maritim, 17(1), 99-109. 